\title{
2027 硬式野球ボールの数值解析モデルと衝突特性 NUMERICAL SIMULATION MODELING AND IMPACT CHARACTERISTICS OF BASEBALLS
}

\author{
○寒河江 智史(法政大院) \\ 内藤 寬之（法政大） \\ 藤川 政宏(法政大院) \\ 時枝 健一(ゼットクリエイト) \\ 藤原 聖司(ゼットクリエイト) 正 新井 和吉(法政大)
}

Satoshi SAGAE, Masahiro FUJIKAWA, Hiroyuki NAITO, Kazuyoshi ARAI, Hosei University, Kajino3-7-2, Koganei-shi, Tokyo Kenichi TOKIEDA, Seishi FUJHARA, ZETT CREATE Corporation, Karasugatsuji 1-4-25, Tennoji-ku, Osaka

In baseball, the ball repeatedly hits a bat, glove, ground, etc. Such impacts, especially the ones with the bat, affect the ball's velocity and horizontal distance. Moreover, the impact with a helmet can be dangerous for human head and hence must be importantly considered. Therefore, the characteristic of the ball's impact is very important from the viewpoint of its performance and to ensure safety. In this study, a model of the ball was investigated for conducting a numerical analysis of the characteristics of the ball's impact with the bat or helmet. Various material properties of the model were determined by an inverse analysis using the data of rebounding velocity obtained by an impact test with a rigid body. Furthermore, the effect of each material property of the ball on the coefficient of restitution of the ball or on the maximum acceleration of a human head model was considered for the analysis.

Key Words : Ball, Numerical analysis, Coefficient of restitution, Maximum acceleration

\section{1. 緒言}

硬式野球において, ボールはバットやグローブ, グラウンドなど との衝突を繰り返している. 衝突現象の中でも, 特にバットとの衝 突は打球速度，飛距離などに大きく影響を及ぼし，2011 年から日 本プロ野球一軍試合統一使用球が, 国際大会使用球に近づけ, 低反 発球に変更されている(1). また, ヘルメットとの衝突では頭部への 危険性から最も考慮されるべき事項である. そのため, ボールの衝 突特性は野球用具の性能や安全性の観点から極めて重要となって いる.

そこで本研究では, 硬式野球ボールとバットやへルメットとの衝 突現象の数值解析を今後行うことを目的に, ボールの数值解析モデ ルの構築を行った. ボールモデルの種々の材料物性值は, 静的強度 試験および模擬剛体との衝突試験により得た反発速度のデータに 基づき逆解析を行うことで決定した. さらに，ボールを構成してい る各材料の物性值がボールの反発係数や人頭模型の最大加速度に 及ぼす影響について検討を行った.

\section{2. ボールの数值解析モデルの検討}

硬式野球ボールの構造は複雑であり, 内側からコルク, ゴム, 毛 系, 牛革の 4 つの材料から構成されている. コルクとゴムは全体の 体積に占める割合が比較的小さく, かつ内部にあるため, 硬式野球 ボールの各材料の中で影響は非常に小さいと考えられる.したがっ て, コルクとゴムは一体の材料とし, ボールを三層構造のモデルと して検討を行った. 解析には衝突解析ソフト (LS-DYNA, (株) JSOL) を用いた. ボールの切断面と数值解析モデル形状を図 1 に示す.

牛革は等方性弹性体と考え, 縦弾性係数は $E=30.7 \mathrm{MPa}$ とし(2), ポ アソン比は $v=0.4$ とした ${ }^{(3)}$. ついで, ゴム・コルク一体材料および 毛系材料は, 動的特性を考慮して等方粘弾性体とし, 粘弾性体モデ ルとして，式(1)に示すマクスウェルモデルとばね要素が並列に結 合した 3 要素モデルを用いた ${ }^{(4)}$.

$$
G(t)=G_{\infty}+\left(G_{0}-G_{\infty}\right) e^{-\beta t}
$$

ここで, $G_{\infty}$ はある時間経過してばね要素のみに特性が依存する静 的な横弾性係数 $[\mathrm{Pa}]$ であり， $G_{0}$ は負荷初期の横弾性係数 $[\mathrm{Pa}], \beta$ は 指数减衰定数 $[1 / \mathrm{s}], t$ は持続時間 $[\mathrm{s}]$ である( ${ }^{(4)}$.これら材料物性值のう ち，ゴム・コルク一体材料の長期せん断係数 $G_{\infty}$ および体積弾性係 数 $K$ は, 静的圧縮試験を行い, 試験と同条件の解析モデルを作成 し, 逆解析により決定した. ゴム・コルク一体材料の静的圧縮試験 における荷重一変位曲線を図 2 に示す。ささらに, ゴム・コルク一体 材料の材料物性值である $G_{0}, \beta$ と毛系材料の材料物性值である $K$, $G_{0}, G_{\infty}, \beta$ は, 日本車両検査協会にて実施した硬式ボールと剛体

壁との衝突試験により取得した反発係数 $V_{2} / V_{1}$ を用いて，圧縮試 験と同様に逆解析により決定した。 ここで， $V_{1}$ は衝突速度， $V_{2}$ は 反発速度である.また, “衝突試験に使用したボールは 2011 年に統 一された公式球と同等品のボールを使用した. 実験および逆解析に よって決定した三層構造ボールの牛革, ゴム・コルク一体材料およ び毛系の各材料物性值を表 1 に示す.

ボールと剛体壁の衝突実験から求めた反発係数と, 決定した材料 物性值を使用して解析から求めた反発係数との比較を図 3 に示寸. 解析值と実験值は良い一致を示していることがわかる.

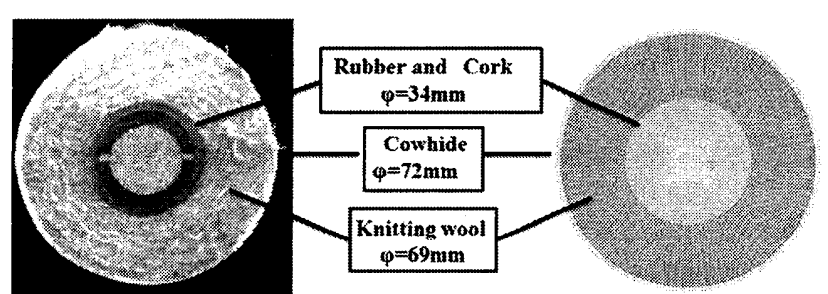

(a)

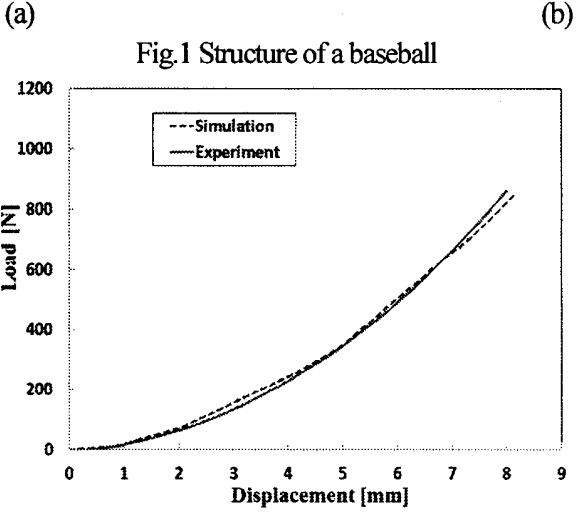

Fig.2 Load-displacement curve of rubber and cork

Table 1 Each parameter of ball model

\begin{tabular}{|c|c|c|c|}
\hline & Rubber and Cork & Knitting Wool & Cowhide \\
\hline Young modulus, $E[\mathrm{MPa}]$ & - & - & 30.7 \\
\hline Poison's ratio, $v$ & - & - & 0.4 \\
\hline Bulk modulus, $K$ [MPa] & 28 & 60 & - \\
\hline Short time shear modulus, $G_{0}[\mathrm{MPa}]$ & 40 & 23 & - \\
\hline Long time shear modulus, $G_{\alpha \mid} M P a \mid$ & 24 & 3.4 & - \\
\hline Time constant, $\beta[1 / \mathrm{s}]$ & 8000 & 31000 & - \\
\hline
\end{tabular}




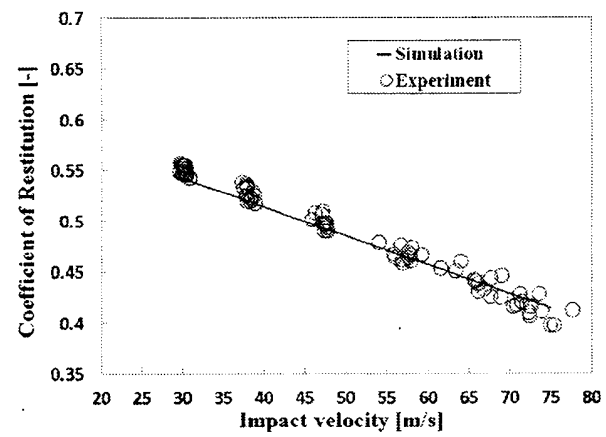

Fig. 3 Comparison of analysis and experimental results of coefficient of restitution

\section{3. 人頭模型衝突における発生加速度の比較}

ボールと 6 面体簡易人頭模型(5) との衝突時におりる発生加速度の 実験値と解析値の比較検討を行った. 6 面体簡易人頭模型の質量は $5.05 \mathrm{~kg}$ ，材質は Mg 合金製であり，衝突面は $90^{\circ}$ とした. 衝突試験 装置には，ガスガン方式のボール発射装置(高圧システム(侏製)を用 い(2)(5)，人頭模型に加わる加速度の測定は，人頭模型の内部に 3 軸の圧電式加速度計(PCB PIEZOTRONICS 製)を設置し，衝突によ って発生する加速度を測定した. 加速度の応答は分析処理器(CAT SYSTEM SA-01，リオン(㑣製)を用いて出力し，3軸を合成させた合 成加速度を求め, その最大値で評価した. 衝突最大加速度の解析値 と実験值の比較結果を図 4 亿示す，反発係数の比較結果と同様に, 衝突最大加速度においても解析值と実験值が良い一致を示してい ることがわかる.

\section{4. ボールモデル諸物性值が反発係数および加速度に及ぼす影響}

構築したボールモデルにおいて，ゴム・コルク一体材料および 毛系材料の各材料物性值 $K, G_{0}, G_{\infty}, \beta$ が焵体衝突時の反発係数 および人頭模型衝突時の最大加速度に及ぼす影響について検討し た. 解析の衝突速度は $30 \mathrm{~m} / \mathrm{s}$ 一定として, 毛系材料の各物性値が反 発係数および最大加速度に及ぼす影響の一例を図 5 に示寸. 毛系の 体積弾性係数 $K$ を増加すると(a), 反発係数恃若干低下するが, 一 方，加速度は最小值となる $K$ 值が存在することがわかる. 初期せ 儿断係数 $G_{0}$ を増加すると(b), 反発係数は低下し, 加速度は体積弾 性係数と同様に最小值となる $G_{0}$ 值が存在することがわかる．長期 せん断係数 $G_{\infty}$ を増加すると(c), 反発係数と加速度は共に増加し, 減衰定数 $\beta$ を増加すると(d), 反発係数は増加し，加速度は低下す る傾向がある. また，ゴム・コルク一体材料の各材料物性值を変化 させた場合も，ほぼ同様の傾向を示す．しかし，ゴム・コルク一体 材料よりも毛糸材料の方が反発係数と衝突最大加速度に及ぼす影 響が大きいことがわかった.これは，ボールを構成する材料におい て, ボール全体に占める体積割合が毛系材料は $77.5 \%$ と非常に大き いためと考えられる.

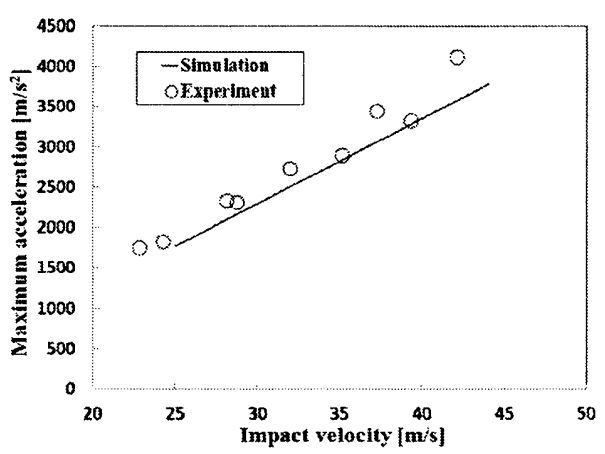

Fig.4 Comparison of analysis and experimental results of maximum acceleration

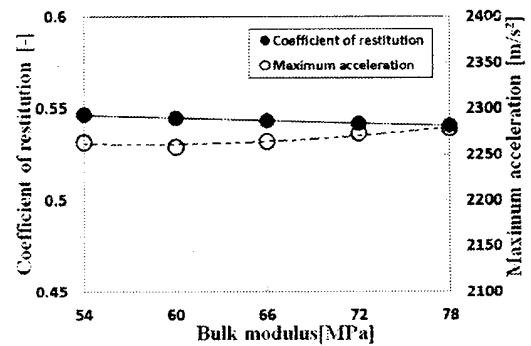

(a) $K$

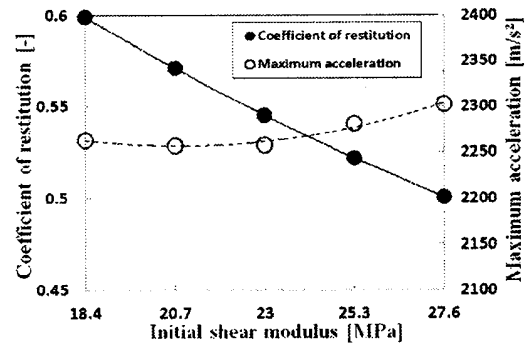

(b) $G_{0}$

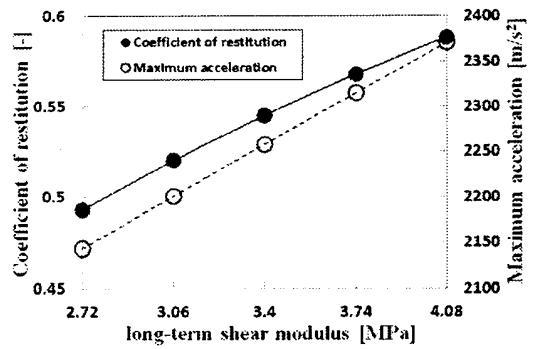

(c) $G_{\infty}$

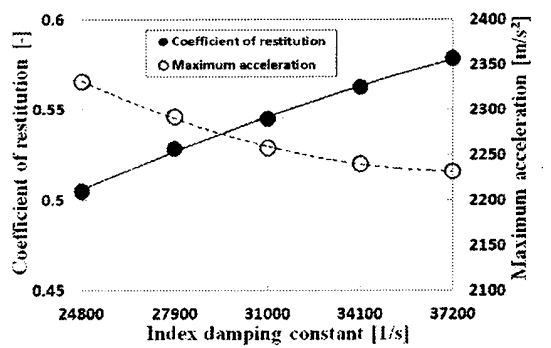

(d) $\beta$

Fig.5 Effects of each parameter of kitting wool on coefficient of restitution and maximum acceleration

5. 結言

1)硬式野球ボールをゴム・コルク，毛糸，牛革の三層構造にてモデ ル化し，各材料物性値を実験值または逆解析により求めた結果, ボールモデルの剛体反発係数と簡易人頭模型衝突時の最大加速 度の解析值は，実験值と良い一致を示すことがわかった。

2)ボールを構成する材料の内, 体積割合の大きい毛系が, 反発係数 と衝突最大加速度に大きな影響を及ぼすことがわかった。 参考文献

(1) 日本野球機構 : http://www.npb.or.jp/CGI/System/news_view. cgi?id $=01615$

(2) 高橋大司朗,硬式野球用 CFRP ヘルメットの性能評価,2010 年度 法政大学大学院工学研究科機械工学専攻修士論文

(3) 尾田十八,酒井忍, 米村茂, 河田憲吾, 野球ボールの衝撃力測定と シミュレーション解析, ジョイント・シンポジウム講演論文集 No.04-26 (2004), pp.100-103

(4) LS-DYNA Version971 User's Manual Volume II

(5) 富岡良平,新井和吉,関将見,森田敏則,岩原光男,長松昭男, 硬式野 球用ヘルメットの繰返し衝突に対する緩衝性能, スポーツ産業 学研究, Vol.19, No.2 (2009), pp.105-111. 